\section{Unusual presentation of oxalate}

\section{nephropathy causing acute kidney injury: A case report}

\section{Anas Diab*, Michelle M Neuman, Kareem Diab and Daniel Gordon}

Department of Medicine, Section of Nephrology, $4^{\text {th }}$ Floor, HSCN Room 4076A, Morgantown, WV 26506, USA

\section{Abstract}

Oxalate nephropathy due to Hyperoxaluria and elevated serum oxalate level is a well-known cause for interstitial fibrosis, and ESRD. Conditions associated with high serum Oxalate, should be considered as a possible contributing factor for a patient's tubular injury.

Well known cause for Hyperoxaluria including enteric Hyperoxaluria (due to gastric bypass, chronic pancreatitis, small Bowel resection, or malabsorption, as well as depletion of enteric oxalate-degrading bacteria [e.g., Oxalobacter). Other known causes of oxalate nephropathy include primary Hyperoxaluria, ethylene glycol intoxication, vitamin B6 deficiency, excessive ingestion of vitamin $\mathrm{C}$ or dietary substances rich in oxalic acid, aspergillosis, prolonged renal failure and various drugs (e.g., Known medications to cause Oxalate Nephropathy are: Orlistat, Praxilene, COX-2 inhibitors)

Unusual presentation with Acute Kidney Injury with incidental finding of high serum Oxalate in a patient with a known CKD stage III, recently started on Polyethelene Glycol to treat his constipation.

\begin{abstract}
More Information
*Address for Correspondence: Anas Diab Department of Medicine, Section of Nephrology, $4^{\text {th }}$ Floor, HSCN Room 4076A, Morgantown, WV 26506, USA, Tel: 304-293-2551;

Fax: 304-293-7373;

Email: anas.diab@hsc.wvu.edu

Submitted: 03 April 2020

Approved: 03 November 2020

Published: 04 November 2020

How to cite this article: Diab A, Neuman MM, Diab K, Gordon D. Unusual presentation of oxalate nephropathy causing acute kidney injury: A case report. J Clini Nephrol. 2020; 4: 077-079.

DOI: 10.29328/journal.jcn.1001063
\end{abstract}

Copyright: (c) 2020 Diab A, et al. This is an open access article distributed under the Creative Commons Attribution License, which permits unrestricted use, distribution, and reproduction in any medium, provided the original work is properly cited.

Keywords: Polyethylene glycol; Oxalate nephropathy; Acute kidney injury (AKI); Hyperoxaluria; Kidney biopsy; End stage kidney disease

Check for updates

OPEN ACCESS

\section{Case presentation}

We report a case of Acute kidney injury in a 68-yearold male, presented to Ruby Memorial Hospital (Teaching hospital of West Virginia Medical School, Morgantown, WV), who required renal replacement therapy due to oxalate nephropathy, has past medical history of diabetes mellitus type 2 (DM), Hypertension, hyperlipidemia, basal cell cancer (removed from his back), chronic back pain, required Narcotic, for which he developed severe constipation and prescribe to use Polyethelen Glycol daily 6 months prior to his admition, presented to ED with generalized malaise, vomiting, and bilateral leg weakness, for 3-4 weeks duration, found with Metabolic Acidosis, and Hyperkalemia, with elevated Serum Creatinine to $7.7 \mathrm{mg} / \mathrm{dl}$, from baseline creatinine $1.4 \mathrm{mg} / \mathrm{dl}$ 6 months prior to admission, his hemoglobin A1C was 6.4\% and he had issues since 2014 controlling his potassium, he had been taking oxycodone since 2009 when he had a shoulder injury at his workplace, using oxybutynin for urge incontinence. Patient is a non-smoker, denies ingestion any kind of alcohol, or using NSAID.
Upon presentation his physical exam showed mild tachypnea with BP 124/86, presence of Retinopathy, no signs of volume depletion or overload ,Chest exam is normal with no rales or wheezing, Heart, regular, with palpable bladder, no Asterexis, but with mild hyperreflexia, with no peripheral edema.

Initial admission laboratory workup table 1 showed potassium of $6.5 \mathrm{mmol} / \mathrm{L}$, in acute kidney injury on a Chronic Kidney Disease stage III, with a creatinine of $7.7 \mathrm{mg} / \mathrm{dL} \mathrm{k}$,

\begin{tabular}{|c|c|}
\hline \multicolumn{2}{|l|}{ Table 1: List of patient medications. } \\
\hline Amitriptyline $75 \mathrm{mg}$ oral tablet & $75 \mathrm{mg}$ tab every night \\
\hline Amlodipine $5 \mathrm{mg}$ oral tablet & $5 \mathrm{mg}$ tab once a day \\
\hline Aspirin $81 \mathrm{mg}$ delayed release oral tablet & $81 \mathrm{mg}$ once a day \\
\hline Probiotics & Once a day \\
\hline Cholecalciferol, vit D3 1000 unit oral tablet & 2 tablets once a day \\
\hline Ferrous sulfate 325 oral tablet & 1 tablet every 6 hours PRN \\
\hline Insulin glargine 100 units/ml subQ injection & 30 units once a day \\
\hline Metformin $1000 \mathrm{mg}$ oral tablet & 1 tablet once a day \\
\hline Paroxetine $20 \mathrm{mg}$ oral tablet & 1 tablet once a day \\
\hline Polyethylene glycol $17 \mathrm{gram} /$ dose oral powder & Once a day \\
\hline Sennosides-docusate sodium $8.6-50$ mg oral tablet & 1 tablet once a day \\
\hline
\end{tabular}


blood urea nitrogen of $77 \mathrm{mg} / \mathrm{dL}$ and serum bicarbonate of $10 \mathrm{mmol} / \mathrm{L}$. An initial urine dipstick showed small blood and $5 \mathrm{mg} / \mathrm{dL}$ no Proteinuria or Hematuria, or crystals, His potassium was treated with IV calcium gluconate, insulin with dextrose $50 \%$, as well as a sodium bicarbonate drip at 150 $\mathrm{mL} / \mathrm{hr}$. A Foley catheter was placed upon admission, yielding $700 \mathrm{~mL}$ of urine, over the next few days, his GI symptoms continue as he was presented, even with gentle hydration and he had a non Oliguric urine output once a Foley catheter was placed, with next 5 days, showed no improvement on his Kidney functions.

A renal ultrasound was obtained, showing normalsized kidneys bilaterally with borderline increased renal echogenicity bilaterally with multiple small stones in both kidneys, with no Hydronephrosis as it shown in figure 1. Serologic workup was ordered (complements, antinuclear antibodies, myeloperoxidase antibodies, proteinase antibodies IgG, double-stranded DNA, ANCA, hepatitis B/C, as well as urine electrolytes, SPEP, and creatinine kinase), all of which were unremarkable/negative.

On day 5, after the admition A renal biopsy was performed , given the non-improvement of his kidney functions, despite resolving his Bladder Outlet Obstruction, and IV hydration, to establish diagnosis, prognosis and for future treatment planning. His kidney biopsy figure 2 showed marked
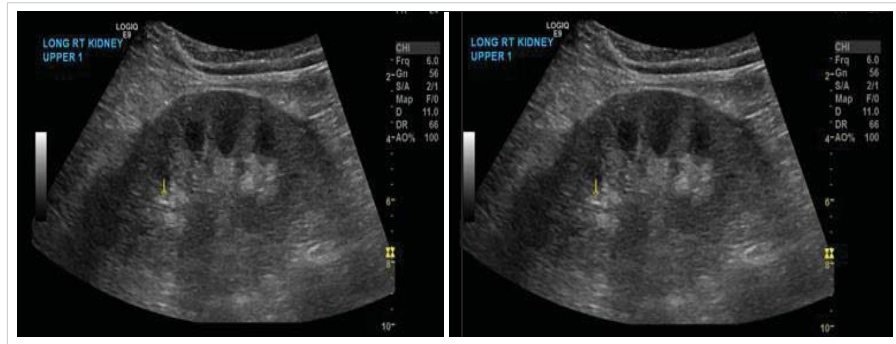

Figure 1: Ultrasound of kidneys demonstrating increased echogenicity and stones.

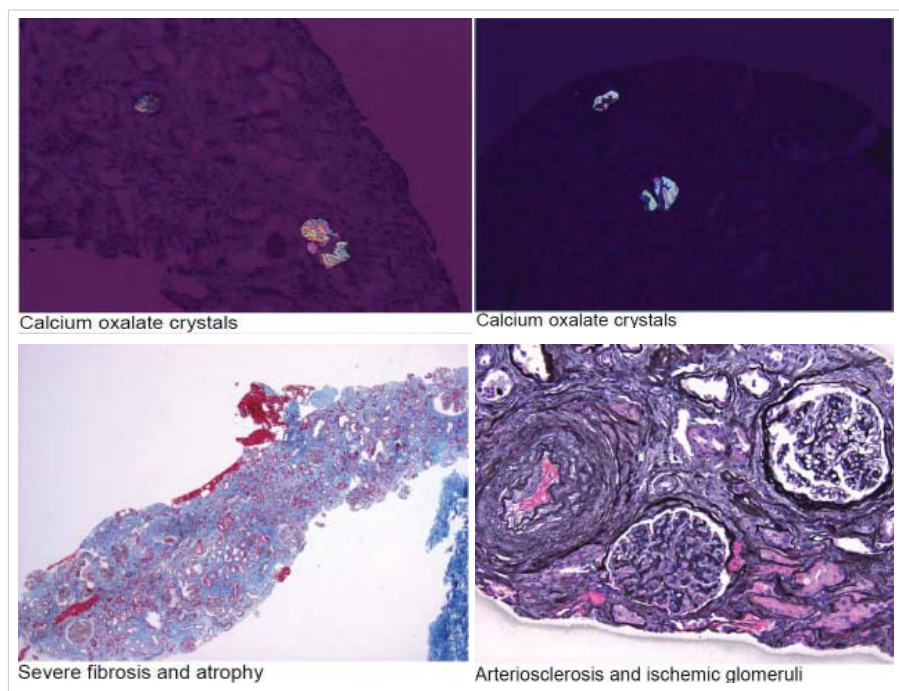

Figure 2: Kidney biopsy. Total Glomeruli were 76. Global Glomerulosclerosis was 15. Interstitial Fibrosis was severe. Tubular atrophy was severe. Arteriosclerosis was severe. Arterial Halitosis was mild. interstitial fibrosis and tubular atrophy in the absence of significant glomerular disease, suggestive of chronic Tubulointerstitial injury. There is abundant calcium oxalate deposition within tubular Lumina. While some calcium oxalate deposition can be seen as a nonspecific finding in patients with acute tubular injury, abundant calcium oxalate, as in this case, raises the possibility of oxalate nephropathy, with no evidence of Diabetic Nephropathy.

Subsequent work up based on the result of his Kidney Biopsy, a 24-hour urine oxalate was collected, showing 0.41 $\mathrm{mmol} / 24 \mathrm{hr}$ (0.11-0.46 mmol/24 hr) and an initial plasma oxalate was $20.4 \mathrm{mcmol} / \mathrm{L}(<1.6 \mathrm{mcmol} / \mathrm{L})$.

On day 6 after the admition, Hemodialysis was initiated with 5 hours sessions, using a Tunneled catheter, as indicated to clear his serum Oxalate, and to treat his moderate uremic symptoms, with daily check on plasma oxalate levels.

Genetic testing was sent to rule out primary Hyperoxaluria as a cause of his renal interstitial oxalate deposition. Genetic results showed a UMOD gene heterozygosity, with uncertain significance [6]. Per genetic report it is uncertain whether this gene had any clinical significance [7].

After patient had received 2 weeks of Dialysis He was

Table 2: Chemistry and $\mathrm{CBC}$

\begin{tabular}{|c|c|c|c|c|}
\hline & \multicolumn{3}{|c|}{ Ref. Range } & Actual \\
\hline SODIUM & \multicolumn{3}{|c|}{ Range: 136 - $145 \mathrm{mmol} / \mathrm{L}$} & $133(\mathrm{~L})$ \\
\hline POTASSIUM & \multicolumn{3}{|c|}{ Range: $3.5-5.1 \mathrm{mmol} / \mathrm{L}$} & $6.5(\mathrm{HH})$ \\
\hline CHLORIDE & \multicolumn{3}{|c|}{ Range: 96 - $111 \mathrm{mmol} / \mathrm{L}$} & 104 \\
\hline CARBON DIOXIDE & \multicolumn{3}{|c|}{ Range: 22 - $32 \mathrm{mmol} / \mathrm{L}$} & $13(\mathrm{~L})$ \\
\hline BUN & \multicolumn{3}{|c|}{ Range: 8 - 25 mg/dL } & $77(\mathrm{H})$ \\
\hline CREATININE & \multicolumn{3}{|c|}{ Range: $0.62-1.27 \mathrm{mg} / \mathrm{dL}$} & $7.10(\mathrm{H})$ \\
\hline GLUCOSE & \multicolumn{3}{|c|}{ Range: 65 - 139 mg/dL } & 127 \\
\hline ANION GAP & \multicolumn{3}{|c|}{ Range: 4 - 13 mmol/L } & $16(\mathrm{H})$ \\
\hline BUN/CREAT RATIO & \multicolumn{3}{|c|}{ Range: 6 - 22} & 11 \\
\hline EGFR & \multicolumn{3}{|c|}{ Range: $>60 \mathrm{~mL} / \mathrm{min} / 1.73 \mathrm{~m}^{\wedge} 2$} & $7(\mathrm{~L})$ \\
\hline CALCIUM & \multicolumn{3}{|c|}{ Range: 8.5 - $10.2 \mathrm{mg} / \mathrm{dL}$} & $8.1(\mathrm{~L})$ \\
\hline MAGNESIUM & \multicolumn{3}{|c|}{ Range: 1.6 - $2.6 \mathrm{mg} / \mathrm{dL}$} & $1.0(\mathrm{LL})$ \\
\hline PHOSPHORUS & \multicolumn{3}{|c|}{ Range: $2.3-4.0 \mathrm{mg} / \mathrm{dL}$} & $4.7(\mathrm{H})$ \\
\hline WBC & \multicolumn{3}{|c|}{ Range: 3.7 - $11.0 \times 10^{\wedge} 3 / \mathrm{uL}$} & 7.3 \\
\hline HGB & \multicolumn{3}{|c|}{ Range: $13.4-17.5 \mathrm{~g} / \mathrm{dL}$} & $8.6(\mathrm{~L})$ \\
\hline $\mathrm{HCT}$ & \multicolumn{3}{|c|}{ Range: $38.9-52.0 \%$} & $26.6(\mathrm{~L})$ \\
\hline PLATELET COUNT & \multicolumn{3}{|c|}{ Range: 150 - $400 \times 10 \wedge 3 /$ LL } & 192 \\
\hline \multicolumn{5}{|c|}{ Urinalysis } \\
\hline \multicolumn{2}{|l|}{ COLOR } & \multicolumn{2}{|l|}{ Range: Normal (Yellow) } & Normal (Yellow) \\
\hline \multicolumn{2}{|l|}{ SPECIFIC GRAVITY, URINE } & \multicolumn{2}{|l|}{ Range: $1.005-1.030$} & 1.008 \\
\hline \multicolumn{2}{|l|}{ GLUCOSE } & \multicolumn{2}{|l|}{ Range: Negative mg/dL } & Negative \\
\hline \multicolumn{2}{|l|}{ BILIRUBIN } & \multicolumn{2}{|l|}{ Range: Negative mg/dL } & Negative \\
\hline \multicolumn{2}{|l|}{ KETONES } & \multicolumn{2}{|l|}{ Range: Negative mg/dL } & $5(\mathrm{~A})$ \\
\hline \multicolumn{2}{|l|}{ BLOOD } & Range: Negative $\mathrm{mg} / \mathrm{d}$ & & Small (A) \\
\hline PH URINE & & Range: $5.0-8.0$ & & 5.0 \\
\hline PROTEIN & & Range: Negative $\mathrm{mg} / \mathrm{d}$ & & Negative \\
\hline UROBILINOGEN & & Range: Negative $\mathrm{mg} / \mathrm{d}$ & & Negative \\
\hline NITRITE & & Range: Negative & & Negative \\
\hline LEUKOCYTES & & Range: Negative WBC & $s / u L$ & Negative \\
\hline CREATININE, UR RAND & & $/ \mathrm{dL}$ & 22 & \\
\hline SODIUM, URINE RAND & & $\mathrm{ol} / \mathrm{L}$ & 62 & \\
\hline OSMOLALITY, URINE & & ge: $50-1,400 \mathrm{mOsm} / \mathrm{kg}$ & 218 & \\
\hline
\end{tabular}


ultimately discharged from the hospital with arrangement for outpatient dialysis, and he is still not declared End Stage Kidney Disease.

\section{Discussion}

In this 68-year-old male, it is unclear as to the direct cause of this patient's elevated serum Oxalate. It is speculated that perhaps long-term supplementation with vitamin D could have increased patient's absorption of oxalate due to increased calcium absorption [5] and deprive the small bowel from the Calcium necessary to bind to the enteral Oxalate. Polyethylene glycol, although rarely, can be depolymerized by anaerobic bacteria to ethylene glycol and diethylene glycol [8] that can be easily absorbed and converted in the liver into multiple substrates including calcium oxalate by enzymes (alcohol dehydrogenase, aldehyde dehydrogenase, lactate dehydrogenase).

In this patient's case his Serum Creatinine was at his Baseline $1.4 \mathrm{mg} / \mathrm{dl}$ before starting his Polyethelene Glycol, and increased to above $7 \mathrm{mg} / \mathrm{dl}$ at the time of presentation, with other factor or factors could have contributed including his CKD 3, chronic Bladder outlet obstruction, with a kidney biopsy showed clear evidence of Oxalate Nephropathy, and while his high serum Oxalate was most likely multifactorial due to the patient being stage 3 CKD and being already prone to oxalate loading from his Polyethylene Glycol, in the absence of Hyperoxaluria gene.

In Chronic Kidney Disease As the glomerular filtration rate falls below 30 to $40 \mathrm{~mL} / \mathrm{min}$ per $1.73 \mathrm{~m}^{2}$, plasma oxalate levels increase because of reduced urinary oxalate excretion [9]. When plasma oxalate exceeds $30 \mathrm{micromol} / \mathrm{L}$, which is the plasma supersaturating threshold for calcium oxalate, calcium oxalate is deposited into other tissues including the retina, myocardium, vessel walls, skin, bone, and the central nervous system.

It is unusual for Oxalate Nephropathy to present in advance age, so the conclusion of Multifactorial high serum oxalate level would be presumed as the trigger factors for his Acute Kidney Injury.
Long term outcome of his kidney functions, would be determine based on follow up during his outpatient Hemodialysis, after eliminating all risk factors for his high serum Oxalate, by stopping his Polyethelene Glycol, and perform Oxalate clearance of his serum Oxalate by using Hemodialysis, and treating his Bladder outlet obstruction.

\section{References}

1. Hill P, Karim M, Davies DR, Roberts ISD, et al. Rapidly progressive irreversible renal failure in patients with pancreatic insufficiency. Am J Kidney Dis. 2003; 42: 842-845.

2. Bleyer AJ, Hart PS, Kmoch S@. Familial Juvenile Gout (Concept Id: C4551496) - MedGen - NCBI." National Center for Biotechnology Information, U.S. National Library of Medicine.

PubMed: www.ncbi.nlm.nih.gov/medgen/1645893

3. Cartery C, Faguer S, Karras A, Cointault O, et al. Oxalate nephropathy associated with chronic pancreatitis. Clin J Am Soc Nephrol. 2011; 6: 1895-1902.

PubMed: https://www.ncbi.nlm.nih.gov/pmc/articles/PMC3359534/

4. Cornell LD. Secondary Oxalosis. In: Colvin RB, Chang A, Farris III BA, Kambham N, et al. (eds). Diagnostic Pathology: Kidney Diseases, 2nd edn. Elsevier: Manitoba. 2016; 736-737.

5. Giannini S, Nobile M, Castrignano R, Pati T, Tasca A, et al. Possible Link between Vitamin D and Hyperoxaluria in Patients with Renal Stone Disease. Clin Sci. 84: 1993, 51-54.

PubMed: https://pubmed.ncbi.nlm.nih.gov/8382134

6. UMOD is a gene that has been associated with autosomal dominant UMOD-related tubulointerstitial kidney disease, previously known as familial juvenile hyperuricemia (gouty) nephropathy type 1, as well as linked to autosomal dominant glomerulocystic kidney disease with hyperuricemia and isosthenuria (2).

7. Autosomal Dominant Tubulointerstitial Kidney Disease, UMODRelated Synonyms: ADTKD-UMOD, Familial Juvenile Hyperuricemic Nephropathy 1, Medullary Cystic Kidney Disease 2, UMOD-Associated Kidney Disease, Uromodulin Kidney Disease Anthony J Bleyer, MD, MS, P Suzanne Hart, PhD, and Stanislav Kmoch, PhD.

8. Biodegradation of Polyethers (Polyethylene Glycol, Polypropylene Glycol, Polytetramethylene glycol, and Others) Part 9. Miscellaneous Biopolymers and Biodegradation of Polymers Prof. Dr. Fusako Kawai. 2005.

9. Perinpam M, Enders $\mathrm{FT}$, Mara KC, Vaughan LE, Mehta RA, et al. Plasma oxalate in relation to eGFR in patients with primary hyperoxaluria, enteric hyperoxaluria and urinary stone disease. Clin Biochem. 2017; 50: 1014-1019.

PubMed: https://www.ncbi.nlm.nih.gov/pmc/articles/PMC5705406/ 